\title{
Digestion of whole-crop grain silage starch in ruminants
}

\author{
P. Micek, F. Borowiec and Z.M. Kowalski \\ Cracow Agricultural University, \\ Department of Animal Nutrition \\ Al. Mickiewicza 24/58, 30-059 Kraków, Poland
}

\begin{abstract}
The effect of cereal species (oat, triticale, rye and barley) and stage of maturity of plants at harvest (heading $-\mathrm{H}$, milk $-\mathrm{M}$, and milk-dough $-\mathrm{MD}$ ) on starch digestion was studied. An in vivo digestibility trial was conducted on 12 wethers. Starch ruminal degradability was determined in situ and postruminal digestibility by the mobile nylon bag technique. Starch from whole-crop cereal silages was nearly completely digested in the digestive tract. Its digestibility significantly increased as plants matured from $\mathrm{H}$ to $\mathrm{M}$ stage $(\mathrm{P}<0.05)$ and then was stable. With the exception of triticale, starch from silages made at $\mathrm{H}$ or $\mathrm{M}$ stages of maturity was entirely digested within $16 \mathrm{~h}$ of incubation in the rumen. In stage MD the highest contents of fraction A $(94.6 \%)$ and starch ERD $(98.1 \%)$ were found for oat silage $(P<0.05)$, and the lowest ERD for barlcy and rye silages $(87.1$ and $82.8 \%$, respectively).

It can be concluded that regardless of cereal species, silages made at stages $\mathrm{H}$ and $\mathrm{M}$ of maturity contain starch that is quickly and completely digested in the rumen. In older plants (MD or later stages), differences in the site of digestion and its extent may occur.
\end{abstract}

KEY WORDS: whole-crop grain silage, stage of maturity, starch, rumen degradability, intestinal digestibility

\section{INTRODUCTION}

The importance of whole-crop grain silages is steadily increasing in Poland. The nutritive value of these forages depends on the cereal species and stage of growth of plants at harvest. Optimum harvesting time is usually a compromise between the highest yield and nutrient availability, which is influenced by the progressing maturity of plants (Mannerkorpi and Brandt, 1995). The lack of effect of maturity stage on organic matter digestibility in silages made from milk or later 
stages is mainly caused by a fast increase in starch content (Mannerkorpi and Taube, 1995). The starch content in whole-crop wheat or barley silages can range from nil for crops harvested at the vegetative stage of growth, to over $250 \mathrm{~g} \mathrm{~kg}^{-1} \mathrm{DM}$ for mature crops (Leaver, 1996). Numerous studies have compared the site and extent of starch digestion from cereal grains (Herrera-Saldana et al., 1990; Żebrowska et al., 1997), but little information on digestion of starch in cereal crops from different species is available, especially for silages. This information can be useful in the choice of cereal species for silage production.

The aim of the present study was to determine the effect of cereal species and stage of plant maturity at harvest on starch digestion in the rumen, small intestine and in the whole digestive tract of ruminants.

\section{MATERIAL AND METHODS}

Whole-crop grain silages were made of oat, triticale, rye and barley, cut at three stages of maturity: heading (H), milk (M), and milk-dough (MD). Plants were harvested, chopped and ensiled with a microbial inoculant additive (Microsil, $10 \mathrm{~g} \mathrm{~T}^{-1}$ fresh forage) in $100 \mathrm{~L}^{-1}$ plastic containers. The dry matter content of silages was determined by the toluene method (Dewar and McDonald, 1961). Chemical composition was determined on dried $\left(45^{\circ} \mathrm{C}, 48 \mathrm{~h}\right)$ and ground samples using standard methods (AOAC, 1995). Starch content was determined by the method of Faisant et al. (1995) and NDF, ADF and ADL by the method of Goering and Van Soest (1970).

In vivo digestibility (IVD) was determined on 12 wethers randomly divided into 3 groups of 4 animals and fed twice a day with silages supplemented with vitamin-mineral premix. In situ starch ruminal degradability was determined by the method of Michalet-Doreau et al. (1987), using 3 rumen fistulated steers fed standard diets. Approximately $3 \mathrm{~g}$ of samples (ground to pass through a $1.5 \mathrm{~mm}$ screen) were placed in nylon bags that were then put in the rumen of steers just before the morning feeding. Incubations ware carried out at 2, 4, 8, 16, 24, 48 and $72 \mathrm{~h}$. Nine measurements (three repetitions and three steers) were made for each incubation time. The effective rumen digestibility (ERD) of starch and digestibility rate constants (A, B, C) were calculated according to Ørskov and McDonald (1979). Postruminal digestibility of starch escaping rumen fermentation was evaluated on 3 steers, about $370 \mathrm{~kg}$ body weight, fitted with rumen and duodenal cannula, using the mobile nylon bag technique (MNB) by Peyraud et al. (1988), as modified by Kowalski et al. (1995). Bags filled with oven-dried $\left(45^{\circ} \mathrm{C}, 48 \mathrm{~h}\right)$ and ground $(1.5 \mathrm{~mm})$ silages were incubated in the rumen for $16 \mathrm{~h}$ and then in $\mathrm{HCl}$-pepsin for $2.5 \mathrm{~h}\left(\mathrm{pH} 2.0,39.5^{\circ} \mathrm{C}\right)$. After inserting into the duodenum, the bags were collected from faeces within $24 \mathrm{~h}$, rinsed and washed. 
The data were subjected to two-way analysis of variance using the GLM procedure of SAS (1995). The individual means were separated by the Student-Newman-Keuls test (SAS, 1995). Differences were considered to be significant at $\mathrm{P}<0.05$.

\section{RESULTS AND DISCUSSION}

Dry matter and starch increased as the maturity of plants progressed $(\mathrm{P}<0.05)$, which was accompanied by a decrease in protein content (Table 1). Mannerkorpi and Brandt (1995) observed the same tendencies in relation to the stage of maturity of barley plants. The highest proportion of starch was in silages prepared at stage MD, especially barley and triticale (210 and $147 \mathrm{~g} \mathrm{~kg}^{-1} \mathrm{DM}$, respectively). According to Edmisten et al. (1998), due to the "dilution" effect of starch, the NDF, ADF and ADL contents increased rapidly between stages $H$ and $M$ and then slightly decreased between stages $M$ and MD.

In vivo digestibility of starch of all silages was high (over $87 \%$ ) (Table 2). Irrespective of species, starch digestion significantly increased $(\mathrm{P}<0.05)$ between $\mathrm{H}(93.4 \%)$ and $\mathrm{M}(99 \%)$ stages of maturity. However, there were no significant differences $(\mathrm{P}>0.05)$ between stages $\mathrm{M}$ and $\mathrm{MW}(99 \%)$. In stage $\mathrm{H}$, silages made of rye and barley had the highest in vivo starch digestibility, triticale and oat silage starch was less but still highly digestible. Regardless of species, starch in silages $\mathrm{M}$ and MD was nearly entirely digested (Table 2).

Due to the high rate and extent of starch digestion, it was difficult to establish the effect of maturity on rumen and intestinal digestibility of starch. Regardless of species, starch in silages $\mathrm{H}$ and $\mathrm{M}$ was entirely digested in the rumen within $16 \mathrm{~h}$. Probably the higher starch content and hardiness of grain caused a decrease in ruminal starch degradability of MD silages. In this stage, a higher starch ERD (98.1) and A parameter (94.6\%) were shown for oat silage (Table 2). The lowest ERD was observed for barley and rye silages ( 87.1 and 82.8 , respectively). These silages also had a lower content of rapidly degradable starch fraction A (65.8 and 63.8, respectively), which was accompanied by a high content of slowly degradable fraction $\mathrm{B}$. The lowest ERD of triticale in stages $\mathrm{H}$ and $\mathrm{M}$ is noteworthy. However, ERD of triticale silage made in the MD stage was higher than for barley or rye silage. According to Żebrowska et al. (1997), the ERD of starch from cereal grains was also the highest for oat and the lowest for barley (winter variety). Based on these findings, it can be concluded that in more mature stages of growth (MD or later) starch digestibility and degradability in the rumen of whole-crop grain silages may be closely connected with the potential availability of starch from cereal grains (Table 2). This was particularly true for MD silages of all species. It is important to point out that except for rye silages, the in vivo total digestive tract starch digestibility was slightly but apparently lower than that determined by the MNB method. 


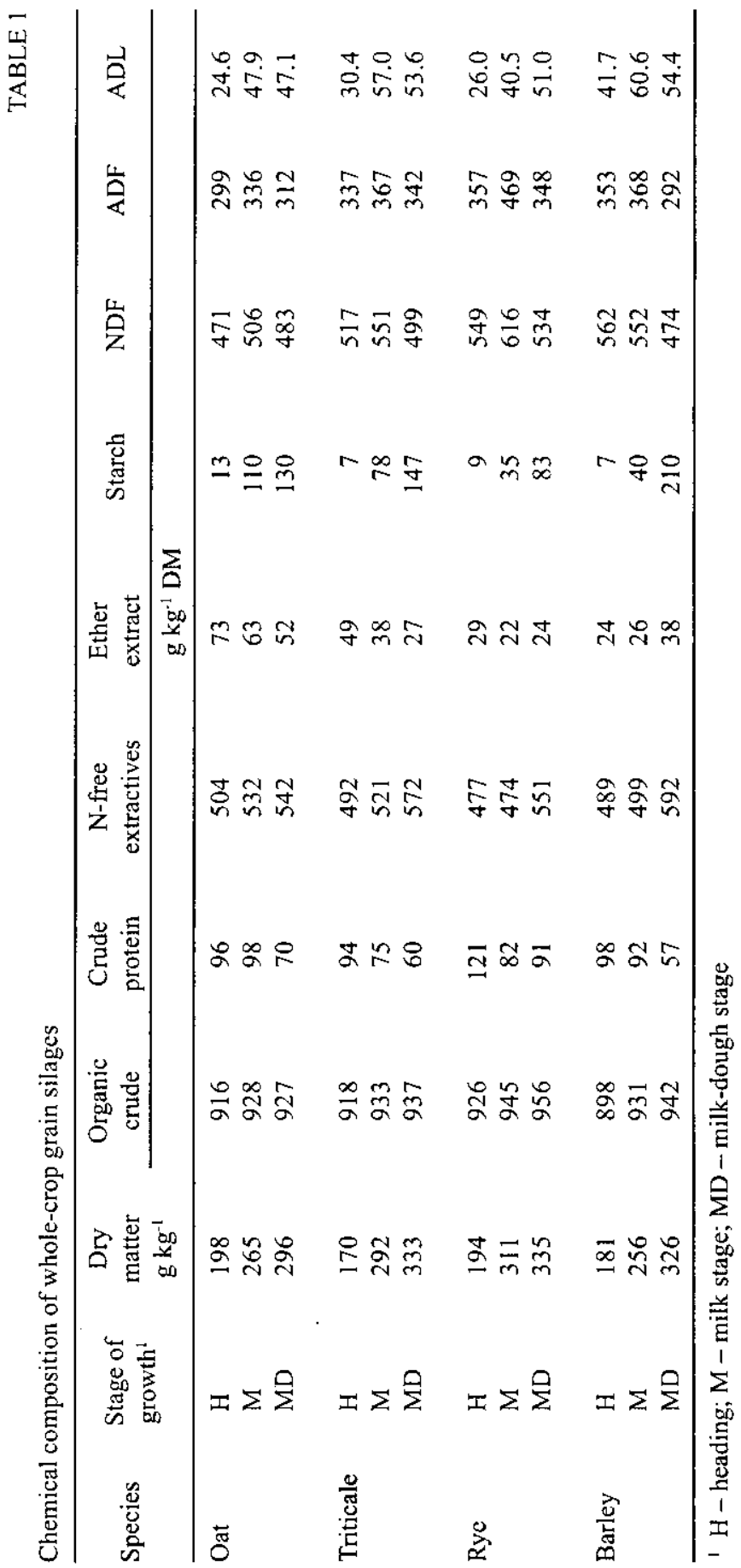


TABLE 2

Starch digestibility of whole-crop cereal silages

\begin{tabular}{|c|c|c|c|c|c|c|c|c|}
\hline \multirow{2}{*}{ Species } & \multirow{2}{*}{$\begin{array}{l}\text { Stage of } \\
\text { growth' }\end{array}$} & \multirow{2}{*}{ in vivo } & \multicolumn{4}{|c|}{ in situ parameters } & \multicolumn{2}{|c|}{$\mathrm{MNB}^{5}$} \\
\hline & & & A & B & $\mathrm{C}$ & ERD & ISD $^{6}$ & $\operatorname{TTSD}^{7}$ \\
\hline \multirow[t]{3}{*}{ Oat } & $\mathrm{H}$ & 89.3 & 100 & 0.0 & 0.000 & 100 & - & 100 \\
\hline & M & 99.1 & 100 & 0.0 & 0.000 & 100 & - & 100 \\
\hline & $\mathrm{MD}$ & 98.8 & 94.6 & 5.5 & 0.115 & 98.1 & 100 & 100 \\
\hline \multirow[t]{3}{*}{ Triticale } & $\mathrm{H}$ & 87.5 & 58.1 & 43.0 & 0.120 & 84.3 & 100 & 100 \\
\hline & M & 98.7 & 93.5 & 6.6 & 0.100 & 97.6 & 100 & 100 \\
\hline & $\mathrm{MD}$ & 98.1 & 91.4 & 8.8 & 0.086 & 96.6 & 100 & 100 \\
\hline \multirow[t]{3}{*}{ Rye } & $\mathrm{H}$ & 100 & 100 & 0.0 & 0.000 & 100 & - & 100 \\
\hline & M & 100 & 100 & 0.0 & 0.000 & 100 & - & 100 \\
\hline & MD & 100 & 63.8 & 37.2 & 0.063 & 82.8 & 100 & 100 \\
\hline \multirow[t]{3}{*}{ Barley } & $\mathrm{H}$ & 96.6 & 100 & 0.0 & 0.000 & 100 & - & 100 \\
\hline & $\mathbf{M}$ & 97.6 & 100 & 0.0 & 0.000 & 100 & - & 100 \\
\hline & MD & 99.6 & 65.8 & 34.3 & 0.100 & 87.1 & 100 & 100 \\
\hline
\end{tabular}

Effect species ${ }^{2}$

$\begin{array}{lccccc}\text { oat } & 95.8^{\mathrm{C}} & 97.8^{\mathrm{A}} & 2.2^{\mathrm{D}} & 0.046^{\mathrm{B}} & 99.2^{\mathrm{A}} \\ \text { triticale } & 94.8^{\mathrm{C}} & 81.0^{\mathrm{D}} & 19.5^{\mathrm{A}} & 0.102^{\mathrm{A}} & 92.8^{\mathrm{D}} \\ \text { rye } & 100^{\mathrm{A}} & 87.9^{\mathrm{C}} & 12.4^{\mathrm{B}} & 0.021^{\mathrm{C}} & 94.3^{\mathrm{C}} \\ \text { barley } & 97.9^{\mathrm{B}} & 88.6^{\mathrm{B}} & 11.4^{\mathrm{C}} & 0.033^{\mathrm{BC}} & 95.7^{\mathrm{B}}\end{array}$

Effect stage of growth ${ }^{2}$

$\begin{array}{lrrrrr}\mathrm{H} & 93.4^{\mathrm{B}} & 89.5^{\mathrm{B}} & 10.7^{\mathrm{B}} & 0.030^{\mathrm{B}} & 96.1^{\mathrm{B}} \\ \mathrm{M} & 98.9^{\mathrm{A}} & 98.4^{\mathrm{A}} & 1.7^{\mathrm{C}} & 0.025^{\mathrm{B}} & 99.4^{\mathrm{A}} \\ \mathrm{MD} & 99.1^{\mathrm{A}} & 80.1^{\mathrm{C}} & 20.2^{\wedge} & 0.093^{\mathrm{B}} & 91.7^{\mathrm{C}}\end{array}$

$\begin{array}{lllccl}\text { Interaction }^{3} & \mathrm{~S} & \mathrm{~S} & \mathrm{~S} & \mathrm{~S} & \mathrm{~S} \\ \text { SEM }^{4} & 0.65 & 2.57 & 2.62 & 0.01 & 1.06\end{array}$

${ }^{1} \mathrm{H}$ - heading, $\mathrm{M}$ - milk stage, MD - milk-dough stage

2 means with the same letter are not significantly different ( ${ }^{\text {a.b.c }} \mathrm{P}>0.05$; ${ }^{\mathrm{A} . \mathrm{B} . \mathrm{C}} \mathrm{P}>0.01$ )

${ }^{3} \mathrm{~S}$ - significant differences $(\mathrm{P}<0.05)$

${ }_{4}$ SEM - standard error of the mcans

5 MNB - postruminal starch digestibility determined by mobile nylon bag technique ( $16 \mathrm{~h}$ incubation in rumen)

${ }^{6}$ ISD - intestinal starch digestibility

7 TTSD - total tract starch digestibility 


\section{CONCLUSIONS}

Starch from whole-crop grain silages is nearly entirely digested in the digestive tract of ruminants. In vivo starch digestibility increases with maturity of plants between heading and milk stage. Starch from such silages is very susceptible to rumen fermentation since it was entirely digested within $16 \mathrm{~h}$ of incubation in the rumen (for heading and milk stages). In MD silages, the highest starch ERD was shown for oat, the lowest for barley and rye silages.

\section{REFERENCES}

AOAC, 1995. Official Methods of Analysis. Association of Official Analytical Chemists. $16^{\text {th }}$ Edition. Arlington, VA

Dewar W.A., McDonald P., 1961. Determination of dry matter in silage by distillation with toluene. J. Sci. Food Agr. 12, 790-795

Edmisten K.L., Green J.T., Mueller P.J., Burns J.C., 1998. Winter annual small grain forage potential. Il. Quantification of nutritive characteristics of four small grain species at six growth stages. Commun. Soil Sci. Plant Anal. 29, 881-899

Faisant N., Planchot V., Kozlowski F., Pacouret M.P., Colonna P., Champ M., 1995. Resistant starch determination adapted to products containing high level of resistant starch. Sci. Alim. 15, 83-89

Goering H.K., Van Soest P.J., 1970. Forage Fiber Analysis. (Apparatus, Reagents, Procedures, and Some Applications). Agric. Handbook No. 379. ARS-USDA. Washington, DC

Herrera-Saldana R.E., Huber J.T., Poore M.H., 1990. Dry matter, crude protein, and starch degradability of five cereal grains. J. Dairy Sci. 73, 2386-2393

Kowalski Z. M., Pisulewski P. M. P., Peyraud J-L., Kamiński J., 1995. The effect of drier outflow temperature on rumen protein degradability and intestinal digestibility of rumen-undegraded protein of dehydrated grass and lucerne. Ann. Zootech. 44, Suppl., 88 (Abstr.)

Leaver J.D., 1996. Supplementation of maize silage and whole crop cereals. In: P.C. Garnsworthy, J. Wiseman, W. Haresign (Editors). Recent Advances in Animal Nutrition. Nottingham University Press, pp. 171-194

Mannerkorpi P., Brandt M., 1995. Feeding value of barley plants as related to stage of maturity. 2. In vivo digestibility and voluntary intake of silages. Acta Agr. Scand., Sect. A. Anim. Sci. 45, $153-158$

Mannerkorpi P., Taube F., 1995. Feeding value of barley plants as related to stage of maturity. 1. Morphological and chemical composition and in vitro digestibility. Acta Agr. Scand., Sect. A. Anim. Sci. 45, 147-152

Michalet-Doreau B., Vérité R., Chapoutot P., 1987. Methodologie de mesure de la degradabilite in sacco de l'azote des aliments dans le rumen. Bull. Tech. C.R.Z.V. Theix 69, 5-7

Peyraud J. L., Genest-Rulquin Ch. R., 1988. Mesure de la digestion de l'azote des aliments dans l'intestin des ruminants par la technique des sachets mobiles. 1. Evaluation de la quantite de matières azotées indigestibles en sachet des principaux aliments. Reprod. Nutr. Devclop. 28, 129-130

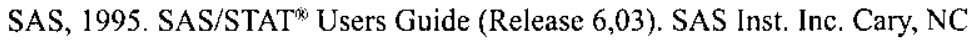


Żebrowska T., Długołęcka A., Pająk J.J., Korczyński W., 1997. Rumen degradability of concentrate protein, amino acids and starch, and their digestibility in the small intestine of cows. J. Anim. Feed Sci. 6, 451-470

\section{STRESZCZENIE}

\section{Strawność skrobi kiszonek z calych roślin zbożowych przez przeżuwacze}

Oznaczono zawartość i strawność skrobi w kiszonkach sporządzonych z całych roślin owsa, pszenżyta, żyta i jęczmienia, zbieranych w okresie kłosienia (H), dojrzałości mlecznej (M) i mleczno-woskowej ziarna (MD). Strawność in vivo oznaczono na 12 tryczkach, strawność w żwaczu oznaczono metodą in situ, a strawność jelitową metodą woreczków mobilnych. W miarę dojrzewania roślin zmniejszała sį̨ zawartość białka ogólnego, a wzrastała skrobi. Skrobia z kiszonek zbożowych była prawie całkowicie trawiona w przewodzie pokarmowym owiec. Jej strawność wzrastała wraz z dojrzałością roślin pomiędzy fazą $\mathrm{H}$ i $\mathrm{M}(\mathrm{P}<0,05)$, a następnie utrzymywała się na tym samym poziomie w fazie $M$ i MD. W fazach $H$ i M skrobia była calkowicie trawiona w ciagu 16 godzin inkubacji woreczków w żwaczu. W fazie MD najwyższy ERD skrobi $(98,1)$ oraz udział frakcji A $(94,6 \%)$ stwierdzono w kiszonce $z$ owsa $(\mathrm{P}<0,05)$, najniższy w kiszonkach z jęczmienia $i$ żyta $(87,1$ i 82,8 , odpowiednio; $P<0,05$ ). Skrobia, która uniknęła rozkładowi $w$ żwaczu, była $w$ całości trawiona w jelitach.

Bez względu na gatunek zboża kiszonki sporządzone $z$ roślin zbieranych w okresie kłoszenia i dojrzałości mlecznej ziarna zawierają skrobię całkowicie i szybko trawioną w żwaczu. Kiszonki sporządzone $\mathrm{z}$ roślin zbieranych w okresie mleczno-woskowej dojrzałości ziarna mogą różnić się tempem oraz miejscem trawienia skrobi w zależności od gatunku zboża. 